\title{
Methicillin-resistant Staphylococcus epidermidis in handler of cheese made with goat's milk in Brazil
}

\section{Breno Bezerra Aragão ${ }^{* *}$ (D) Sabrina Cândido Trajano ${ }^{2}$ (D) Renata Pimentel Bandeira de Melo ${ }^{4}$ (D) Bruno Pajeú e Silva ${ }^{3}$ (D) Rinaldo Aparecido Mota ${ }^{4}$ (D)}

${ }^{1}$ Programa de Pós-graduação em Biociência Animal, Universidade Federal Rural de Pernambuco (UFRPE), 52171-900, Recife, PE, Brasil. E-mail: breno.aragao100@hotmail.com. "Corresponding author.

${ }^{2}$ Programa de Pós-graduação em Medicina Veterinária, Universidade Federal Rural de Pernambuco (UFRPE), Recife, PE, Brasil.

${ }^{3}$ Programa de Pós-graduação em Ciência Animal Tropical, Universidade Federal Rural de Pernambuco (UFRPE), Recife, PE, Brasil.

${ }^{4}$ Departamento de Medicina Veterinária, Universidade Federal Rural de Pernambuco (UFRPE), Recife, PE, Brasil.

ABSTRACT: In the Northeastern Brazil, artisanal cheese production is an important local economic activity for small producers. Methicillinresistant Staphylococcus is responsible for causing infection in animals and humans. This study described the first detection of methicillinresistant $S$. epidermidis isolated in the nasal cavity of a handler of coalho cheese made with goat's milk in Northeastern Brazil. This brief communication highlighted the importance of adopting biosafety measures by cheese handlers, in order to reduce possible contamination and the spread of pathogens in the production chain of this type of artisanal cheese in Brazil.

Key-words: goat cheese, antimicrobial resistance, one health.

Staphylococcus epidermidis resistente à meticilina em manipulador de queijo elaborado com leite de cabra no Brasil

RESUMO: Na região Nordeste do Brasil, a cadeia de produção de queijo artesanal é uma atividade local importante para pequenos produtores. Staphylococcus resistentes à meticilina são responsáveis por causar infecções em animais e seres humanos. Neste estudo descrevese a primeira detecção de $S$. epidermidis resistente à meticilina isolado da cavidade nasal de um manipulador de queijo coalho elaborado com leite de cabra no Nordeste do Brasil. Este relato destaca a importância da adoção de medidas de biossegurança por manipuladores de queijo, a fim de reduzir possíveis contaminações e a disseminação de patógenos na cadeia produtiva deste tipo de queijo artesanal no Brasil. Palavras-chave: queijo de cabra, resistência antimicrobiana, saúde única.

Antimicrobial resistance (AMR) is considered to be one of the greatest threats to humans and animal health. For many years, studies on AMR and the spread of resistant infectious agents have primarily focused on isolates from clinical samples. Currently, research reveals a different dynamic in the food production chain, which is considered the main route of transmission of antibiotic-resistant bacteria (CHAJĘCKA-WIERZCHOWSKA et al., 2015).

Artisanal coalho cheese made with goat's milk stands out among the food carriers of pathogenic microorganisms in Brazil (OLIVEIRA et al., 2019). This food originates in the Northeastern Brazil, has high socioeconomic importance, and is widely consumed in the region. Usually, its manufacture is made with raw milk and undergoes thermal processing during production. Despite its importance, production techniques are not standardized, and the facilities are frequently inadequate, which increases the risk of contamination (QUEIROGA et al., 2013).

Contaminated artisanal cheeses are important vehicles for pathogenic agents such as Coagulase Negative Staphylococcus (CoNS) species, especially $S$. epidermidis (ALNAKIP et al., 2019). Methicillin-resistant Staphylococcus is considered a serious public health problem as it is resistant to all $\beta$-lactams (except the latest generation cephalosporins) (PEACOCK \& PATERSON, 2015). The presence of $S$. epidermidis in the production chain of artisanal goat cheese, such as coalho, can 
be considered a risk to the consumers. Despite this, studies on the subject in Brazil are still scarce.

The study described the occurrence of methicillin-resistant Staphylococci in the nasal cavities of a handler coalho cheese made with goat's milk in Brazil.

For the detection of Staphylococci, a total of six swab samples were collected from one milker and two cheese handlers, in addition to seven swab samples from the utensils used in the production of coalho cheese made with raw goat milk on a rural property in the state of Pernambuco, Brazil (Figure 1).

Two swabs, one from hands and one from nasal cavities, were collected from each employee directly involved in the production chain. As well as swabs from two buckets used in milking goats, the sieve used to filter the milk collected, cheese making table and cheeses' molds. The swab samples were soaked in tubes with Mueller-Hinton broth (Difco Laboratories Inc., Detroit, United States) with $0.3 \%$ sodium chloride and all samples were packed in isothermal boxes with recyclable ice and transported immediately to the laboratory where the microbiological and molecular analyzes were carried out

The bacterial isolation of samples from milker, handlers and utensils was performed by streak plating on Salt Mannitol Agar (Difco Laboratories Inc., Detroit, United States) enriched with egg yolk emulsion (HiMedia, Mumbai, India). The plates were incubated in a bacteriological oven at $37^{\circ} \mathrm{C}$ for 24 to 48 hours. After this time, the reading was carried out to check the existing colonies. The Matrix-Associated Laser Desorption/Ionization - Time of Flight MALDI-TOF (Bruker Daltonics, Massachusetts, United States) technique was used to identify the isolates according to the methodology described by WOLTERS et al. (2011). After the identification of S. epidermidis by MALDI-TOF, the colonies were plated again on Base Agar (Difco Laboratories Inc., Detroit, United States), added with 5\% of sheep blood and incubated in a bacteriological oven at $37^{\circ} \mathrm{C}$ for 24 hours. Then, the thermal extraction of DNA was performed according to the methodology described by FAN et al. (1995).

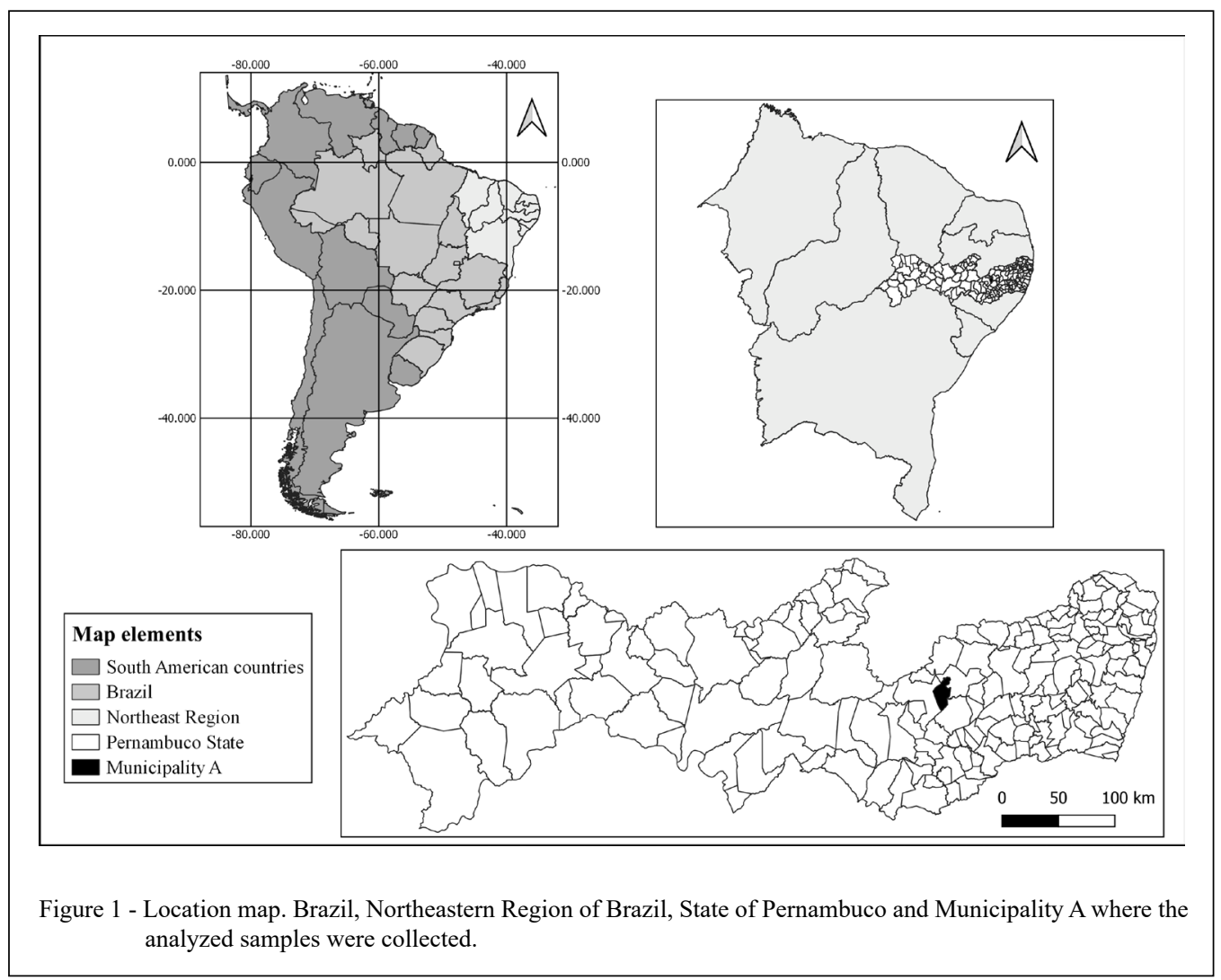

Ciência Rural, v.51, n.8, 2021. 
For screening the isolates for the presence of mecA gene the methodology described by NAKAGAWA et al. (2005) was used. The amplified product was subjected to agarose gel electrophoresis $(1.5 \% \mathrm{w} / \mathrm{v}$ in TAE buffer) to check the presence of 155 base pair (bp) fragment. Positive PCR amplified products were purified using the QIAquick Purification Kit $\left(\right.$ Qiagen $\left.^{\circledR}\right)$, following the manufacturer's protocol, and forwarded for sequencing. Bidirectional sequencing was performed by standard protocol using BigDye Terminator v3.1 Cycle sequencing kit (Applied Biosystems ${ }^{\circledR}$ ). Subsequently, the sequences were analyzed using the $\operatorname{Staden}^{\circledR}$ software (HALL, 1999) and bases with Phred value greater than 20 were maintained. Sequences were compared with the database of the National Center for Biotechnological Information (NCBI) using the basic local alignment search tool (BLAST). The sequence was evaluated on GenBank ${ }^{\circledR}$ (www.ncbi.nlm.nih.gov/genbank/).

The isolate carrying the mecA gene was subjected to disk diffusion test to evaluate the phenotypic resistance of the isolate. The $S$. epidermidis inoculum equivalent to 0.5 on the McFarland scale was plated on the Mueller-Hinton Agar plate (Merck, Germany), followed by the addition of antibiotic discs (Oxoid, Poland) and incubation at $37{ }^{\circ} \mathrm{C}$ for 24 hours. The inhibition zone was interpreted according to the Clinical Laboratory Guidelines of the Standards Institute (CLSI, 2015). The antibiotics tested were cefoxitin (CFO $30 \mu \mathrm{g}$ ), ampicillin (AMP 10 $\mu \mathrm{g}$ ) and oxacillin (OXA $1 \mu \mathrm{g}$ ). The $S$. aureus N315 strain was used as positive control.

A total of 14 isolates were obtained: three from the milkers' hands (Staphylococcus spp., Staphylococcus hominis and S. saprophyticus), two from handlers' hands (Staphylococcus spp. and $S$. saprophyticus), two from the handlers' nasal cavities (Staphylococcus spp. and S. epidermidis), two from the milking buckets ( $S$. epidermidis and Kocuria rhizophila), one from the sieve (Cellulosimicrobium cellulans), two from the cheese molds (Staphylococcus spp. and Staphylococcus saprophyticus), and two from the tables (Staphylococcus spp.).

Bacteria of Staphylococcus genus were the most frequent in this study. Of these Staphylococcus spp. isolates identified by MALDI-TOF, only one $S$. epidermidis, which was isolated from the handler's nasal cavitiy, presented the mecA gene.

The sequence of Methicillin-resistant Staphylococcus (MRSE) amplified product showed similarity of $98 \%$ with strains of $S$. aureus carrying the mecA gene. MRSE isolate showed phenotypic resistance to all antibiotics tested, which suggested a possible pathogenic potential of the isolate, given its phenotypic resistance to antimicrobials in the in vitro analysis.

The high frequency of Staphylococcus bacteria in the artisanal goat cheese production environment reveals inadequate condition for handling utensils and sanitization (PICOLI et al., 2006). Regarding Kocuria rhizophila and Cellulosimicrobium cellulans, they are considered opportunistic bacteria and this is the first report of their detection in the cheese production chain in Brazil. Although, these bacteria were never responsible for causing foodborne disease, there are reports of Kocuria rhizophila causing persistent blood infection (MOISSENET et al., 2012) and Cellulosimicrobium cellulans causing infections in immunosuppressed patients and orthopedic implants (MAGRO-CHECA et al., 2011).

The occurrence of MRSE in a handler of coalho cheese made with goat's milk is a concerning in the production, as this is the first report of its occurrence in Brazil. Although, milk and goat coalho cheese were not analyzed in this study, microorganisms can contaminate these foods by improper handling. MRSE has already been isolated from other types of artisanal cheeses in the world, being an emerging pathogen and considered an important source of transmission of methicillin resistance (ALNAKIP et al., 2019; CHAJĘCKA-WIERZCHOWSKA et al., 2019).

Results obtained indicated the presence of antimicrobial resistance in neglected foodborne microorganisms and the potential publichealthrisks related to the consumption of artisanal cheese contaminated by CoNS species (FONTES et al., 2013). Also, it suggested that strains of CoNS resistant to methicillin may be running in artisanal coalho cheese made with goat's milk, being a possible risk to its consumers.

The occurrence of MRSE in goat coalho cheese handler is an important finding that should be considered for the microbiological food safety. Moreover, it is alarming, as it reveals the existence of methicillin-resistant strains of Staphylococcus in a possible food source contamination. This brief communication highlighted the importance of adopting biosafety measures by cheese handlers, in order to reduce possible contamination and the spread of pathogens in the production chain of this type of artisanal cheese in Brazil.

\section{ACKNOWLEDGEMENTS}

We thank the Centro de Tecnologias Estratégicas do Nordeste (CETENE), for the cooperation on the MALDI-TOF technique, and Fundação de Amparo à Ciência e Tecnologia do Estado de Pernambuco (FACEPE) for the scholarship (IBPG0467-5.05/17). 


\section{BIOETHICS AND BIOSSECURITY COMMITTEE APPROVAL}

The entire experimental procedure is in accordance with the ethical principles adopted by the Human Ethics Committee of Universidade de Pernambuco, license CAAE: 94618718.8.0000.5207.

\section{DECLARATION OF CONFLICT OF INTEREST}

The author(s) declared no potential conflicts of interest with respect to the research, authorship, and/or publication of this article.

\section{AUTHORS' CONTRIBUTIONS}

All authors contributed equally for the conception and writing of the manuscript. All authors critically revised the manuscript and approved of the final version.

\section{REFERENCES}

ALNAKIP, M.E. et al. Molecular characterisation and typing the methicillin resistance of Staphylococcus spp. isolated from raw milk and cheeses in northwest Spain: A mini survey. International Dairy Journal, v.89, p.68-76, 2019. Available from: <https://www sciencedirect.com/science/article/abs/pii/S0958694618302279>. Accessed: May, 02, 2020. doi: 10.1016/j.idairyj.2018.09.006.

CHAJĘCKA-WIERZCHOWSKA, W. et al. S. epidermidis strains from artisanal cheese made from unpasteurized milk in Poland Genetic characterization of antimicrobial resistance and virulence determinants. International Journal of Food Microbiology, v.294, p.55-59, 2019. Available from: <https://www.sciencedirect. com/science/article/abs/pii/S01681 60518304306?via\%3Dihub $>$. Accessed: May, 02, 2020. doi: 10.1016/j.ijfoodmicro.2019.02.004

CHAJECKA-WIERZCHOWSKA, W. et al. Coagulase-negative staphylococci(CoNS) isolated from ready-to-eat food of animal originphenotypic and genotypic antibiotic resistance. Food Microbiology, v.46, p.222-226, 2015. Available from: <https://www.sciencedirect. com/science/article/pii/S0740002014001981?via\%3Dihub>. Accessed: May, 04, 2020. doi: 10.1016/j.fm.2014.08.001.

CLSI - Clinical and Laboratory Standards Institute, 2015. Performance Standards for Antimicrobial Susceptibility Testing, 25th ed. Clinical and Laboratory Standards Institute, 950 West Valley Road, Suite 2500, Wayne, Pennsylvania 19087 USA (CLSI supplement M100 (ISBN 1-56238-989-0 [Print]; ISBN 1-56238-990-4 [Electronic]) Available from: <https://www.facm.ucl.ac.be/intranet/CLSI/CLSI2015-M100-S25.unlocked.pdf>. Accessed: May, 04, 2020.

FAN, H.H. et al. Application of polymerase chain reaction with arbitrary primers to strain identification of Mycoplasma gallisepticum. Avian Diseases, v.39, p.729-735, 1995. Available from: <https:// www.jstor.org/stable/1592409?seq=1\#metadata_info_tab_con tents>. Accessed: May, 04, 2020. doi: 10.2307/1592409.

FONTES, C.O. et al. Prevalence, Antimicrobial Resistance, and Virulence Characteristics of mecA-Encoding Coagulase-Negative Staphylococci Isolated from Soft Cheese in Brazil. Journal of Food Science, v.78, p.594-599, 2013. Available from: <https:// onlinelibrary.wiley.com/doi/abs/10.1111/1750-3841.12088>. Accessed: Mai. 04, 2020. doi: 10.1111/1750-3841.12088.

HALL, T.A. BioEdit: a user-friendly biological sequence alignment editor and analysis program for Windows 95/98/NT. Nucleic Acids Symposium Series, v.41, p.95-98, 1999. Available from: $<$ https:// www.scienceopen.com/document?vid=8b59b929-3c37-49f6936b-f8bf6dd92ace>. Accessed: Mai. 04, 2020. doi: 10.14601/ Phytopathol Mediterr-14998u1.29.

MAGRO-CHECA, C. et al. Septic Arthritis Due to Cellulosimicrobium cellulans. Journal of Clinical Microbiology, v.49, n.12, p.4391-4393, 2011. Available from: <https://www. ncbi.nlm.nih.gov/pmc/articles/PMC3233015/>. Accessed: Jul. 30, 2020. doi: https://doi.org/ 10.1128/JCM.05058-11.

MOISSENET, D. et al. Persistent Bloodstream Infection with Kocuria rhizophila Related to a Damaged Central Catheter. Journal of Clinical Microbiology, v.50, 4, p.1495-1498, 2012. Available from: <https://www.ncbi.nlm.nih.gov/pmc/articles/PMC3318534/>. Accessed: Jul. 30, 2020. doi: 10.1128/JCM.06038-11.

NAKAGAWA, S. et al. Gene sequences and specific detection for Panton-Valentine leukocidin. Biochemical and Biophysical Research Communications, v.328, p.995-1002, 2005. Available from: <https://www.sciencedirect.com/science/article/abs/pi i/ S0006291X05000586?via\%3Dihub>. Accessed: Mai. 04, 2020. doi: 10.1016/j.bbrc.2005.01.054

OLIVEIRA, A.P.D. et al. Characterisation of Staphylococcus aureus strains from milk and goat cheese and evaluation of their inhibition by gallic acid, nisin and velame of the Brazilian caatinga. International Journal of Dairy Technology, v.70, p.112, 2019. Available from: <https://onlinelibrary.wiley.com/doi/ abs/10.1111/1471-0307.12673>. Accessed: Jul. 30, 2020. doi: $10.1111 / 1471-0307.12673$

PEACOCK, S.J.; PATERSON, G.K. Mechanisms of Methicillin Resistance in Staphylococcus aureus. Annual Review of Biochemistry, v.84,p.577-601,2015.Available from: $<$ https://www. annualreviews.org/doi/full/10.1146/annurev-biochem-060614034516? url ver $=Z 39.88-2003 \&$ rfr id $=$ ori\%3Arid\%3Acrossref. org\&rfr_dat $=$ cr pub\%3D pubmed $>$. Accessed: May, 04, 2020. doi: 10.1146/annurev-biochem-060614-034516.

PICOLI, S.U. et al. Quantification of Coliforms, Staphylococcus aureus and Mesophiles present in different stages of the production of fresh goat milk cheese in dairy products. Ciência e Tecnologia de Alimentos. v.26, n.1, p.64-69, 2006. Available from: <https:// www.scielo.br/scielo.php? script $=$ sci abstract\&pid $=$ S010120612006000100011\&lng $=$ en\&nrm $=\mathrm{iso} \& \operatorname{lng}=\mathrm{pt}>$. Accessed: Jul. 30, 2020. doi: 10.1590/S0101-20612006000100011.

QUEIROGA, R.C.R.E. et al. Nutritional, textural and sensory properties of Coalho cheese made of goats', cows' milk and their mixture. Lebensmittel-Wissenschaft \& Technologie, v.50, p.538544, 2013. Available from: <https://www.sciencedirect.com/ science/article/pii/S0023643812003477>. Accessed: Jul. 30, 2020. doi: 10.1016/j.lwt.2012.08.011.

WOLTERS, M. et al. MALDI-TOF MS fingerprinting allows for discrimination of major methicillin-resistant Staphylococcus aureus lineages. International Journal of Medical Microbiology, v.301, p.64-68, 2011. Available from: <https://www.sciencedirect. $\mathrm{com} / \mathrm{sc}$ ience/article/abs/pii/S143842211000072X?via\%3Dihub>. Accessed: May, 04, 2020. doi: 10.1016/j.ijmm.2010.06.002. 